\title{
Os caminhos da "Quase memória" em Nancy Huston e Carlos Heitor Cony
}

\author{
The paths of "Almost memory" in Nancy Huston and Carlos Heitor Cony \\ Vanessa Massoni da Rocha \\ Universidade Federal do Rio de Janeiro - Rio de Janeiro - Rio de Janeiro - Brasil \\ $\diamond$
}

\begin{abstract}
Resumo: Este trabalho propõe uma reflexão sobre a escrita memorialística no romance canadense Cantique des plaines, de Nancy Huston, de 1993 e no romance brasileiro Quase memória, de Carlos Heitor Cony, de 1995. Trata-se de privilegiar na tessitura dos romances o binômio 'memória e morte' e investigar o papel incontornável da memória como elo espaçotemporal entre avós, pais e filhos. Neste sentido, contemplaremos as relações entre a escrita, o luto e os diálogos entre o lembrar e o esquecer.

Palavras-chave: Escrita da memória; "Quase memória"; Nancy Huston; Carlos Heitor Cony; Literatura canadense; Literatura brasileira
\end{abstract}

\begin{abstract}
This paper proposes a reflection on the writing of the memory in Canadian novel Cantique des plaines, by Nancy Huston, 1993 and in the Brazilian novel Almost memory, by Carlos Heitor Cony, 1995. We prioritize in the writing of novels the binomial 'memory and death' and investigate the inescapable role of memory as spatio-temporal link between grandparents, parents and children. In this sense, we will contemplate the relationships between writing, the mourning and the dialogues between remembering and forgetting.

Keywords: Written from memory; "Almost memory"; Nancy Huston; Carlos Heitor Cony; Canadian literature; Brazilian literature
\end{abstract}

Mas, quando de um antigo passado nada permanece, após a morte de seres humanos, após a destruição de coisas, apenas mais frágeis que perenes, mais imateriais, mais persistentes, mais fiéis, o cheiro e o sabor permanecem ainda muito tempo, como almas, a se lembrar, a esperar sobre a ruina de todo o resto, sobre uma gotinha quase impalpável, o edifício imenso da recordação.

(Proust, 2004, p. 46)

Em um destes encontros casuais promovidos por leitores que não cessam de aproximar leituras, o romance brasileiro Quase memória, publicado em 1995 por Carlos Heitor Cony dialoga de perto com o romance canadense Cantique des plaines, Nancy Huston, de 1993. Ambos apontam para o papel incontornável da memória como elo espaço-temporal entre avós, pais e filhos. Este último fala da herança deixada pelo avô que acabara de falecer, já no primeiro, o jornalista Carlos Heitor Cony recebe um envelope que acredita ser do pai, falecido há dez anos.

Os personagens Paddon e Paula do romance Cantique des plaines poderiam ser apresentados pelas palavras profecia e promessa. Muito mais do que um avô e uma neta unidos pelo gosto das histórias e das descobertas, estes personagens se complementam em uma ciranda de encontros e desencontros e se confundem em um projeto épico de escrita sobre o tempo.

Em Quase memória, o envelope chega às mãos de Cony de maneira fortuita, deixado por um hóspede do hotel onde ele almoçava e se soma às várias correspondências que recebe diariamente: convites, divulgação de livros, pedidos de resenha. Seria apenas mais um envelope em uma rotina repleta deles. Seria mais um envelope se não fosse aquela a letra do pai, o borrão da caneta-tinteiro do pai e o nó feito com a delicadeza e a minúcia típicas do pai. "Era a letra de meu pai. A letra e o modo. Tudo no 
embrulho o revelava, inteiro, total" (CONY, 1995, p. 10). Embrulho nas mãos, Cony o investiga nos mínimos detalhes e se convence de que "tudo no envelope o revelava: ele, o pai inteiro, com suas manias e cheiros. Apenas uma coisa não fazia sentido. Estávamos em novembro de 1995. E o pai morrera, aos noventa e um anos, no dia 14 de fevereiro de 1985" (CONY, 1995, p. 11).

Ao invés de abrir o embrulho em um gesto único e apressado, gesto natural para alguém à beira de romper uma década de luto e de ausência do pai, Cony se deixa levar pelas sensações que ele evoca. Como ele define, "estou concentrado em olhá-lo, senti-lo, cheirá-lo" (CONY, 1995, p. 35). Observa o nó e lembra que as mãos do pai estiveram ali. Consegue sentir uma profusão de cheiros que emanam do pacote. Lembra-se de três cheiros inconfundíveis que acompanharam a trajetória do pai: o da brilhantina, o da alfazema e o da manga. Os cheiros, caprichosos que são, não vêm sozinhos, carregam consigo muitas histórias e reatualizam um passado adormecido. $\mathrm{O}$ cheiro da brilhantina, presente do pai quando de sua entrada no seminário. Brilhantina confiscada por um padre e mais tarde descoberta, o pote vazio, nos pertences do mesmo. O cheiro da alfazema que acompanhava e anunciava sua chegada e, por fim, o cheiro da manga. E Cony passa rápida e incontornavelmente do cheiro da manga ao hilário episódio do roubo no cemitério no qual seu pai caiu em cima de coroas de flores durante o enterro de um seminarista ao tentar colher sua fruta favorita.

O primeiro palpite de Cony era que tal presente só poderia ser uma das grandes ideias do pai, uma das suas criativas e surpreendentes maneiras de estar por perto e de ser cúmplice como sempre fez. "Onde quer que estivesse e como estivesse, ele daria um jeito de se fazer sentir, de estar presente" (CONY, 1995, p. 12), e o envelope nada mais era do que mais uma de suas façanhas para se aproximar do filho ou de lhe "embaralhar o caminho" (CONY, 1995, p. 11). Embaralhar o caminho, uma definição curiosa para o presente do pai, presente que confunde e suspende o tempo, convite que aproxima as duas gerações ao mesmo tempo em que marca os revezes da distância e mostra a irrevogável presença da morte. O presente embaralha o caminho pois suspende a organização do jornalista, confunde suas referências e transforma os contornos de sua rotina. Com o embrulho, muda o tempo, muda o espaço, muda Cony: seria aquele diante do envelope o adulto saudoso ou o filho cúmplice? Seria aquele o jornalista respeitado ou o filho de Ernesto Cony Filho, jornalista pioneiro do Jornal do Brasil?

Ao embaralhar o caminho, o envelope se apresenta como chave promissora para o passado. Tal como a Madeleine de Proust cujo gosto remete à lembranças de um tempo que já passou, o embrulho - sem precisar ser aberto - evoca momentos da vida do pai, momentos da infância do narrador e até momentos anteriores ao seu nascimento. São, o bolo e o envelope, pretextos para um retorno, um olhar para trás, uma volta a flashes capazes de refazer toda uma vida. Mesmo que Cony fale de Proust e se recuse a promover comparações, por considerar que sua escrita nem sequer se aproxima da produção acadêmica do escritor de $A$ la recherche du temps perdu, as analogias acontecem naturalmente e não podem ser evitadas. Jacques Le Goff (2003) reconhece o nascimento de uma memória romanesca através da escrita de Proust, escritor que se tornou símbolo do desejo de se recuperar o tempo que já passou através da rememoração vivenciada pela escrita. Proust nos permite descobrir a importância de reviver ficcionalmente o passado, de maneira involuntária e, também, consciente. Garante que ficam resíduos dos seres que já partiram, defendendo a tese de que há sempre algo depois do que acreditamos ser o fim. Depois da morte e da destruição ficam o cheiro e o sabor, elementos capazes de fazer lembrar e de se oferecer como pequenas gotas quase impalpáveis deste imenso edifício que é a lembrança.

Camus nos propõe em seu romance $O$ estrangeiro uma leitura da relação entre a prisão e a lembrança. Fazendo jus à ideia de Proust, fala que o protagonista Meursault aprendeu a não mais se entediar na prisão no momento em que aprendeu a se lembrar. Aqui, lembrar para passar o tempo: objetivo que substitui a afetividade presente em Proust por uma busca racional pelos efeitos da memória. Nas escritas ficcionais, lembrar para registrar a passagem do tempo e, de algum modo, retê-lo. A técnica de Meursault consistia em se lembrar do quarto e, em seguida, se lembrar de cada móvel, de cada objeto, de cada cor ou deformação de toda a decoração. Tudo se passava como se houvesse um detalhado inventário a ser feito. Depois de algumas semanas, ele confessa que poderia passar horas somente a rememorar o que havia em seu quarto. Descobre, então, a máxima de que "quanto mais eu refletia mais coisas desconhecidas e esquecidas saíam da minha memória" (CAMUS, 1990, p. 123), exemplificando de que modo a memória precisa ser trabalhada e visitada pelas pessoas. Em seguida, Meursault compreende o mecanismo entre memória e ficção, o jogo voluntário e involuntário que existe em se viver e em se contar o vivido. "Compreendi então que um homem que teria vivido apenas um dia poderia com facilidade viver cem anos numa prisão. Ele teria lembranças suficientes para não se entediar" (CAMUS, 1990, p. 123). Para Camus um dia somente poderia assegurar uma eternidade de recordações. Bastaria, para isso, que a pessoa reformulasse e reinventasse de maneira criativa suas lembranças. Como se uma cena de decompusesse em várias peças, um quebra-cabeça desfeito, cada peça repleta de detalhes e de possibilidades 
narrativas. O quarto visto por todos os ângulos, em todas as partes do dia. Os objetos vistos em um lugar, depois em outro, com nova cor, novo formato e nova função. Um eterno recomeçar que parece não ter fim. Jogo de impressões e de ficção. Lembrar, associar, pensar em pessoas naquele quarto, pensar em um quarto às avessas, um quarto vazio, um quarto com outros objetos. A lista de possibilidade é tão infinita quanto as possibilidades da memória. A possibilidade de se criar imagens - e textos - a partir de um único dia, um único momento, ou de toda uma vida confundida em diversos momentos. A imposição de um dia nos parece mais contundente, pois nos faz pensar no limite aparentemente exíguo das lembranças. Porém, o mecanismo do jogo entre lembrar, esquecer e se fazer ficção se mostra o mesmo, pelo tempo de um dia ou de noventa anos.

Meursault se dedica às lembranças como mecanismo para passar o tempo e, de alguma maneira, sair dos limites da prisão e reviver sua trajetória. Parece motivado por uma questão de sobrevivência, um apelo à lucidez e a uma ação intelectual capaz de fazê-lo esquecer as imposições da solidão e das impossibilidades. Lembrar para vencer a morte, vencer a angústia da espera e a dificuldade do enclausuramento.

Aqui, nos perguntamos se Paula, narradora de Cantique des plaines, faz uso do mesmo recurso. Se, por um lado, fica claro que os manuscritos herdados a impulsionam a escrever sobre o avô, a escrita do seu texto incorpora menos os fragmentos recuperados dos manuscritos do que suas lembranças. Neste sentido, não seria a morte do avô por si só a chave que abre as portas para a realização da promessa da neta? Ela escreveria mesmo sem ter acesso aos manuscritos? Tal como Cony, ela não escreve por uma vontade de rever a vida de seu ente paterno, narrar sua vida, fazê-lo presente e lograr sua morte? Logo, as narrativas se realizam graças ao desejo de ambos os "filhos", vontade ou movimento natural de se lembrar de momentos importantes no percurso daqueles mestres.

A presença da comunicação epistolar se inicia na correspondência que a avó envia a Paula, um envelope com todo o legado deixado pelo avô. Ao fazer uso do envelope, Karen dá início a uma comunicação entre os dois imediatamente após a morte do marido. Parece convidar a neta a respondê-lo, a manter-se unida a ele, a contrariar sua morte e seu silêncio, enfim, a viver seu luto de um modo menos tradicional e mais criativo. Landowski acredita que a escrita epistolar possa "preencher esse vazio que a motiva" (LANDOWSKI, 2002, p. 168), uma vez que, antes mesmo de receber uma resposta - é possível que nunca a recebamos-, o remetente já consegue preencher o vazio e o silêncio que o impulsionaram a escrever. Já se sente mais próximo e acolhido pelo destinatário porque se lançou no restabelecimento de um diálogo restaurador. Isto acontece porque a "carta tem valor de ato" (LANDOWSKI, 2002, p. 168), porque, ainda durante sua escrita, nos permite pensar na reação do futuro leitor e nos desdobramentos que poderão ocorrer.

Tal como Paula que se debruça na tarefa de ler e reler os escritos do avô, Cony se permite "esgotar o pacote" (CONY, 1995, p. 80) recebido. Trata-se de um momento de encontro, de cumplicidade, momento sem pressa nem hora prevista para terminar. Momento de grande investimento afetivo e corporal, em que cada detalhe do objeto investigado - seja ele um embrulho ou umas folhas escritas - se mostra capaz de descortinar elementos da personalidade e da vivência daqueles que não mais estão ali. E, justamente por não mais estarem ali, estes objetos - seus representantes diretos - ganham importância simbólica de troféus e heranças legados aos seus merecidos herdeiros.

Ecléa Bosi nos apresenta em seu livro $O$ tempo da memória uma reflexão sobre a importância dos objetos na vida e na lembrança das pessoas. A escritora nos apresenta Violette Morin que estuda os objetos que nomeia de "biográficos", reconhecidos por envelhecerem junto com as famílias e se incorporarem à suas vidas. Como defende Ecléa Bosi, "cada um desses objetos representa uma experiência vivida, uma aventura afetiva do narrador" (BOSI, 2003, p. 26). Ao contrário dos objetos "de status" que se aliam a uma tendência da moda e não se enraízam no imaginário, os objetos biográficos são vistos como companheiros e grandes desencadeadores de lembranças do tempo passado e de entes queridos que já se foram. Para Ecléa Bosi:

se a mobilidade e a contingência acompanham nossas relações, há algo que desejamos que permaneça imóvel, ao menos na velhice: o conjunto de objetos que nos rodeiam. [...] Mais que uma sensação estética ou de utilidade eles nos dão um assentimento à nossa posição no mundo, à nossa identidade. (BOSI, 2003, p. 25, 26)

Estes objetos são legados aos herdeiros graças às relações afinadas e cúmplices que tiveram com os pais. Paula insiste em ser a neta predileta de Paddon, usando seus jogos e sua promessa como prova de companheirismo irrefutável. Cony, por sua vez, demonstra ciúme da relação com o irmão mais velho e insiste, reiteradas vezes, ser "a plateia mais fiel" (CONY, 1995, p. 76), "o admirador das habilidades do pai" (CONY, 1995, p. 45) e o "filho deslumbrado" (CONY, 1995, p. 176).

O certo é que, diante de suas heranças, Paula e Cony se permitem andar "pelas ruas da memória" (CONY, 1995 , p. 213), ruas que parecem sem fim, ruas capazes de transformar de maneira constante a vida dos filhos 
que decidem escrever, prender nas linhas do papel vidas que, de tão admiradas, passam a se tornar modelos. Representados pelos filhos, Paddon e Ernesto se tornam grandes homens e passam com muita dignidade e verdade pelos percalços da vida. São, sem dúvida, embelezados pelos olhares nada imparciais de seus admiradores, olhares capazes de enxergar grandeza e coragem em atos aparentemente nada heroicos. Olhares capazes de contornar os lados negativos, como os insucessos na vida profissional, as traições e a segunda família que ambos formaram. Assim, nestas "ruas da memória" os filhos andam com a liberdade de quem quer contar boas histórias e evocar os fortes elos de suas relações com o pai.

Cony afirma que "tanto o nó como o envelope se ofereceram à memória" (CONY, 1995, p. 198) e reconhece a gama de associações e o desfile de lembranças que se perfilam e se sucedem em uma velocidade e um encontro sem fim. Tudo se passa como se a chave do passado chave representada pelo envelope - , abrisse uma porta e que, atrás desta porta, muitas outras se oferecessem à saudade e ao deleite do filho. Como um jogo labiríntico de muito fôlego, o filho tinha diante de si cada vez mais portas, uma remetendo à outra e de certa forma juntando estes pequenos fios em um fio maior, o fio da vida do pai que insiste em não ser cortado.

De repente, todos estes fantasmas, todos estes mortos pareciam estar ali, não na Sala de Imprensa da Prefeitura, mas em minha sala, olhando o embrulho, apreciando a última do papai, que todos esperavam não ser a última de verdade, pois as histórias em que ele se metia nunca tinham fim, ligavam-se umas às outras, entravam uma dentro da outra, como aquelas bonecas de madeira que se fabricam na Rússia. (CONY, 1995, p. 97)

Vistos como portas, ou como bonecas da Rússia, as "ruas da memória" são muitas e por isto muitas representam convites para um longo passeio, passeio com muitas idas e vindas, com atalhos nem sempre mais simples, passeios que, por vezes, demonstram um caminhar desgovernado, sem rumo, um caminho guiado pela lembrança, por suas imposições e seus percursos não muito claros. Caminho fragmentado e marcado por uma inconfundível sedução: aproximar fatos, lugares, tempos e pessoas, mesmo que por um tempo preciso, seja ele de alguns minutos, de um dia ou o tempo exato de se escrever um romance.

"Tempo que ficou fragmentado em quadros, em cenas que costumam ir e vir de minha lembrança, lembrança que somada a outras nunca forma a memória do que fui ou do que os outros foram para mim" (CONY, 1995, p. 102). Justamente por terem a intenção de seguir nossa memória fragmentada as narrativas de Cony e de Paula recusam a obedecer a cronologia previsível dos fatos. Vivas e fugazes que são, rompem com qualquer paradigma e se deixam guiar pelos apelos vindos de perto ou de muito longe. Ao falar de Paddon, Paula pensa em sua concepção, na vida de imigrantes, nos seus avós e cria uma narrativa do avô, de si mesma e de seus pais, uma narrativa que vai muito além dos quase noventa anos de vida do avô. Cony pretende falar de suas lembranças durante o convívio com o pai, mas é capaz de falar de momentos que não vivenciou, usando sua narrativa para registrar as memórias do pai, memórias muito anteriores ao seu nascimento.

Assim, narrativas a quatro mãos, estes filhos se deixam guiar pelos "saltos mortais da memória" (CONY, 1995, p. 109) e escrevem sobre lembranças que já não sabemos se viveram ou conheceram pelo discurso dos pais. Pois a memória tem este caráter polivalente de dar conta do imaginário individual, sendo ele vivenciado de fato ou não. Em Cantique des plaines, Paula é capaz de contar brigas dos seus bisavós que foram presenciadas por Paddon quando ele ainda era pequeno e, talvez, vá mais longe ainda ao revelar a secreta relação entre o avô e Miranda. Cony brinca e se deslumbra com a capacidade do pai de contar histórias e de dar várias versões para o mesmo fato, versão adaptada ao auditório e ao momento. Seu pai nos é apresentado como um grande e fascinante contador de histórias, homem capaz de grandes coisas e de grande imaginação:

Tudo o que mais tarde viemos a saber foi fruto da imaginação do pai, que aproveitando dois ou três elementos da misteriosa biografia do amigo criou um ser fantástico, onisciente, capaz de fabricar perfumes e explosivos [...] Giordano era um deus exilado em Niterói que o pai descobrira com exclusividade e devorava com gula. (CONY, 1995, p. 38)

Nancy Huston fala sobre a necessidade de se revisitar lembranças de vez em quando: "Uma lembrança, é preciso visitá-la de vez em quando. É preciso alimentá-la, sair com ela, dar-lhe ar, mostrá-la, recontá-la aos outros ou a si mesmo. Sem o que, ela enfraquece" (HUSTON, 1999, p. 99). De alguma maneira, Cony identifica o embrulho como uma "despedida suplementar, um pleonasmo de adeus" (CONY, 1995, p. 155), um ato voluntário do pai: dar uma piscadela e dizer que, apesar de tudo, ainda está presente: "Acho que o pai me mandou este embrulho para isso mesmo, para que eu abrisse espaço e ficasse pensando nele - embora eu nunca tenha deixado de nele pensar, de forma fragmentada, a partir de pequeninas coisas da minha vida e da dos outros" (CONY, 1995, p. 179). Ato de aproximação, como o vivenciado por Paula, para quem "em mim os mortos vivem mais intensamente que os vivos. Sem dúvida, é por isso que sua voz, Paddon, começou a cantar fortemente em mim quando 
você morreu..." (HUSTON, 1993, p. 271). E assim, os envelopes se oferecem como despedida suplementar, um adeus que se reitera e se apresenta transformado nas páginas de biografias ficcionais. Um adeus que nasce a partir do momento em que os narradores se permitem "curtir a memória" (CONY, 1995, p. 179), brincar com ela, lembrar-se dos momentos felizes, infinitos.

E através do lembrar, seja pela fala ou pela escrita, estes pais assumem o papel de "personagens preferidos" (CONY, 1995, p. 149), protagonistas de uma narrativa onde as vozes e a narração se confundem, ao ponto de não sabermos quem escreve sobre quem. Parece, então, pertinente um retorno ao título dos romances. Cantique des plaines evoca o livro dos cânticos que Paddon levou junto de si quando deixou de viver: "duas mãos brancas gordinhas e peludas fecham com uma batida o livro dos cânticos" (HUSTON, 1993, p. 11). Fechamento de um livro que acena e se mostra o fio condutor no caminho para a escrita de outro livro, de outros cânticos. Um livro renascimento que não é mais aquele, mas que também não é totalmente outro, um livro que habita neste espaço criativo que une as duas fronteiras, um livro que ocupa o espaço do entre, do quase.

Não por acaso, Cony atribui o título de Quase memória a seu livro, e procura defini-lo como "uma quase-memória, ou um quase romance, uma quasebiografia. Um quase-quase que nunca se materializa em coisa real como este embrulho, que me foi enviado tão estranhamente. E, apesar de tudo, tão inevitavelmente" (CONY, 1995, p. 102). Um livro-quase, pois se baseia e se confunde no limiar da memória, se inscrevendo em uma instância que não sabemos se real ou fictícia, se reprodução do acontecido ou se impressão, criação. Um livro do quase, pois ainda não há, ou talvez nunca haverá, gênero ou nomenclatura capaz de abarcar textos plurais que não se deixam aprisionar por fórmulas já consagradas. Um livro do quase, pois, de alguma maneira, escrever implica o ato de criar ficções, como aquela consagrada pelo poeta, "que chega a fingir que é a dor que deveras sente" (PESSOA, 1997, p. 176). Um livro do quase pois, livro colagem, assume em si a ficção, o romance e as lembranças e se permite brincar com a possível fragilidade de suas convicções. Cony trata de maneira irônica estas fragilidades já no prefácio de seu "quase-romance", prefácio que nos é apresentado como "teoria geral do quase". Segundo Cony,

prefiro classificá-lo como "quase-romance" - que de fato o é. Além da linguagem, os personagens reais e irreais se misturam, improvavelmente, e, para piorar, alguns deles com os próprios nomes do registro civil. Uns e outros são fictícios. Repetindo o antiherói da história, não existem coincidências, logo, as semelhanças, por serem coincidências, também não existem (CONY, 1995, p. 7).
Huston também brinca com a teoria do quase ao permitir que sua protagonista confesse: "Cheguei até aqui, Paddon e de repente não consigo mais escrever palavra alguma nem escutar nem ver nem acreditar em um único detalhe desta vida que eu me esforço para inventar para você. É um processo muito misterioso" (HUSTON, 1993, p. 269).

Ainda sobre o fato destes filhos se lançarem no processo de escrita, podemos ressaltar que, através de sua Quase memória, Cony retorna ao mundo ficcional depois de uma pausa de vinte e dois anos. Naquela época, o jornalista havia prometido a si mesmo não mais escrever ficção por considerar esgotadas todas as suas ideias. Cabe à Quase memória, então, a importância de unir pai e filho graças à inquestionável habilidade de contar histórias. Segundo o site pessoal do escritor: "Cony acreditou nesse pai e faz com que todos nós acreditemos" (http://www. carlosheitorcony.com.br) e talvez esteja aí a importância e o jogo maior do fazer literário: a liberdade de acreditar ingenuamente em boas histórias.

E de tanto acreditarmos nas histórias de Cony, seu livro Quase memória foi premiado com dois Jabutis: melhor romance e livro do ano em ficção, além de ter sido eleito o livro do ano pela Câmara Brasileira do Livro. Ele foi, igualmente, traduzido para o francês em um contrato com a Gallimard e teve uma versão cinematográfica autorizada apenas um ano após sua publicação. Grande marco na carreira do escritor, Quase memória foi escolhido para apresentar Cony em sua publicação, A morte e a vida, de 2008.

Este romance marca o fim de um jejum literário de décadas e inaugura um novo período de grande efervescência ficcional. Desde sua publicação, Cony publica regularmente seus escritos e tem seu trabalho reconhecido por inúmeros prêmios. A entrada para a Academia Brasileira de Letras em 2000 talvez seja o maior deles.

Segundo Cony, o pai "mesmo dormindo, dava a impressão de que realizava grandes coisas" (CONY, 1995, p. 85). E, sem dúvida, a maior destas grandes coisas foi mostrar ao filho os caminhos de volta para a escrita literária. Apesar da autoria desconhecida, o envelope bastou por si só como presença paterna convidativa que remeteu à necessidade de contar histórias e de se reinventar o cotidiano.

Paula nos dá pistas importantes sobre sua solidão e sua escrita sobre Paddon:

Dia após dia me sento à minha mesa em Montreal, fecho meus olhos e aguço meus ouvidos e pouco a pouco uma voz aparece e começa a cruzar as planícies, através da praia e às vezes seu canto é repleto de nostalgia e às vezes ele é alegre, me contanto sobre Miranda, me contando sobre três filhos, me revelando muitas coisas sobre eu mesma e meu pai quebequense que se chama Paul (HUSTON, 1993, p. 269). 
É através da escrita que Paula vive e trabalha o seu luto, escrevendo sua versão para fatos e buscando remediar seu abandono pelo viés ficcional. Ao escrever todos os dias Paula se oferece uma nova existência na qual onde não é vítima da partida das pessoas. Ao escrever ela segura com firmeza as rédeas de sua trajetória, perfazendo caminhos e mudando a ordem das coisas. Ao precisar contar aos outros suas lembranças, Paula brinca com o ditado "quem conta um conto aumenta um ponto" e tece com inventividade os lados desconhecidos de sua família. É diante do papel em Montreal que Paula se permite observar Paddon. Sua narrativa se mostra mais complexa do que a de Cony no plano narrativo na medida em que Paula nos brinda com vários e divergentes olhares sobre o avô. Ao lado de seu olhar cúmplice de neta, há o olhar dos filhos, dos pais, da irmã, do diretor da escola e de Miranda.

Dentre estes olhares, o do filho mais velho, Frankie, merece nossa atenção. Frankie mantém uma relação difícil com pai e acredita que todos na família se curvam cegamente às suas manias despropositadas. Diante dos irmãos, afirma que o pai é um impotente que "nunca fez uma grande coisa e (....) que jamais fará" (HUSTON, 1993, p. 244). Indo na contramão de Cony, para quem o pai sempre fazia grandes coisas, Frankie reconhece que todos os problemas de Paddon são inventados por ele mesmo e por sua contínua automutilação. Termina seu discurso falando que o pai adora fazer um pequeno teatro, uma pequena encenação, para convencer a todos e seguir fazendo tudo o que deseja. Paula comenta esta tumultuada relação ao relatar que na festa de oitenta anos de Paddon, Frankie ficou consternado em ver como seu pai era indigno das homenagens, do carinho e da presença de todos os familiares. Prontamente se lembrou de que ninguém observava o bolo feito com sacrifício pela mãe e que todas as atenções se voltavam, como sempre, para aquele que menos merecia, aquele que nunca tinha se preocupado com sua família e que culpava a todos por sua incompetência e por sua frustração. Ainda nesta festa, Frankie se prepara para "destruir" (HUSTON, 1993, p. 295) o pai e revelar suas mentiras e traições e só não realiza seu intento porque acaba sendo petrificado pelos poderes sobrenaturais de suas filhas gêmeas, Pearl e Amer, que percebem o desejo de pai e decidem ajudar o avô.

É certo que todas estas versões não deixam de ser romanceadas, mas elas deixam transparecer para o leitor que o projeto de Paula é tirar o avô da incompreensão dos que não souberam lê-lo como ele merecia. De alguma maneira, Paula nos diz que só ela leu o verdadeiro Paddon, que só ela conseguiu ver além da aparência melancólica que confundiu e limitou a interpretação dos demais.

Orgulhosa de sua empreitada, Paula ousou bisbilhotar as características de Paddon "que permaneceram entre parênteses, fechadas à chave, abandonadas pelo esquecimento" (HUSTON, 1993, p. 135), características que encantavam Miranda e Paula, únicas mulheres que souberam amar e ser amadas por Paddon. E justamente por se tratar destas características entre parênteses, partes do entre, do quase, que a neta escreve com a liberdade e a segurança de quem conhece ou busca conhecer detalhes importantes que construíram o avô. Não por acaso os manuscritos do avô ficavam escondidos em um porão, também não por acaso em uma crise de raiva por não conseguir escrever, ele joga no aterro sanitário seus textos, uma "verdadeira montanha de angústia revolta" (HUSTON, 1993, p. 195). Não é à toa que Paula fala das antigas caixas de papelão do sótão, caixas que assim como o envelope, se mostram para ela e para Cony como inventário do percurso dos pais.

Cony fala da existência de um quarto dos fundos onde havia "uma infinidade de sua vida, de seu passado" (CONY, 1995, p. 95), quarto que conheceu quando havia ajudado o pai durante sua arrumação. Era um quarto onde estavam velhas cartas, caixas de charuto, velhos cadernos, bules quebrados, toda uma infinidade de velhos objetos que constituíam as lembranças e troféus da vida do pai. Como Cony insiste em dizer, talvez esteja ali o pai "inteiro", tão inteiro quanto Paddon em suas caixas no porão. Inteiros, pois envolvidos na ideia de que ser completo é estar ligado ao passado e às suas lembranças. Inteiros por terem dificuldade de abandonar seus objetos e escritos, companheiros fiéis de outra época que se encontravam momentaneamente trancados em um quarto. Objetos e escritos à espera da visita restauradora de filhos e netos capazes de lhes mostrar novas possibilidades. Objetos e escritos à espera de Cony e de Paula, que souberam, através de narrativas biográficas e memoriais, relançar à vida seus entes queridos.

Tanto quanto Selena no romance Trois fois septembre, Paula e Cony escrevem "a fim de encontrar mais tarde esta felicidade de cores e contornos ingênuos para saboreá-la" (HUSTON, 1989, p. 122). Não por acaso Nancy identifica uma relação entre a escrita e a culinária, ao confessar "para mim, escrever se parece muito com cozinhar... mas sem receita. O que é um projeto possivelmente delirante" (HUSTON, 2004, p. 31). Ambos se encontrariam nos caminhos imprevisíveis da experimentação, da reciclagem, na lacuna inventiva e surpreendente entre os projetos e sua realização. Naquele espaço de investimento corporal, misto de curiosidade e ansiedade de se chegar a um resultado. Momento de ação efetiva cujos frutos merecem ser saboreados, revividos plenamente. Saboreados como conquista e prova sensorial da vitória diante de um desafio. Pois eis que temos, nós leitores de Paula e de Cony, histórias deliciosas em nossas mãos, histórias que seguiram tão somente o preceito da 
não receita, do improviso, da busca de se contar verdades e mentiras, grandes verdades ou pequenas mentiras, ou seria o inverso? Entregues ao nosso encantamento, são quase memórias que não nos convidam a um adeus, mas a um cumprimento emocionado, um agradecimento dos filhos a seus pais.

Em 1992, Nancy Huston publica um livro escrito com a filha Léa. Primeiro de uma série de outros livros que escreveria com os filhos, Véra veut la vérité se insere no que chamamos de percurso anterior ao romance Cantique des plaines. Chamamos de movimento anterior, pois reconhecemos nestas narrativas elementos embrionários que serão reunidos e aprofundados em Cantique des plaines: a herança, a morte e seus desdobramentos na escrita.

A narrativa se passa em torno da difícil compreensão e aceitação da morte e mostra a surpresa de Véra ao descobrir que assim como uma folha de árvore, todos os seres que nascem precisam da morte para concluir seu ciclo de vida. Aparentemente conformada com as explicações nada convincentes dos pais, Véra vivencia com dificuldade a morte do avô e descobre na memória um meio de matar suas saudades.

A gente acredita também em uma vida depois da morte, mas é outro tipo de vida. Isto quer dizer, vovô deixou de viver, mas ele viverá muito tempo na nossa memória [...] E também, todos os gestos que ele fez em vida, todos as palavras que ele disse, todas as canções que ele cantou nos bares tocando violino - você percebe? Tudo isto permanece vivo de alguma maneira, por que isto influenciou outros pensamentos e outros movimentos... (HUSTON, 1992, p. 64,65).

Mais uma vez, retomamos aqui a ideia ilustrada magistralmente por Drummond. Em seu poema "Resíduo", Drummond defende a ideia de que "de tudo fica um pouco" (ANDRADE, 1984, p. 93), um pouco de nós nos outros, um pouco dos outros em nós mesmos, um pouco dos objetos, um pouco dos lugares, um pouco dos odores, um pouco de pouco. Mesmo trabalhada pelos esquecimentos, nossa memória retém sempre um pedaço de lembrança, uma amostra de tudo o que se mostrou importante. Assim, fica em Miranda a história de seu povo e sua dificuldade diante da assimilação sofrida. Fica em Paddon um pouco de Miranda, um pouco de sua infância nas planícies, um pouco de suas ideias sobre o tempo. Fica em Paula um pouco de Paddon, de sua infância, de seu amor incondicional. Fica no romance escrito por Paula um pouco dela mesma, de Paddon, de Miranda, de toda uma família viva nas lembranças e presentificada pelo trabalho da escrita. Fica o resíduo da vida de quadro gerações, o resíduo da história do oeste canadense, o resíduo de histórias de encontros e de desencontros que acompanham tantos personagens, uma história evocada pela memória e enriquecida pela imaginação. Fica da morte um resíduo da vida, fica do esquecimento um resíduo de lembrança, fica da promessa um resíduo da profecia.

De tudo fica um pouco porque nos esquecemos bastante. Sobre a importância do esquecimento imprescindível para o trabalho da memória - Nancy Huston revela no romance Une adoration que "[...] a gente esquece. Felizmente! Sem isto, sem esta preciosa faculdade do esquecimento, a gente nadaria em uma massa indissolúvel de impressões antigas e recentes, desprovidas de hierarquia e sentido" (HUSTON, 2003, p. 161, 162).

Logo, podemos dizer que a memória se mostra capaz de desencadear uma "cadeia infinita" (HUSTON, 1992, p. 66), uma cadeia sem fim capaz de entrelaçar vários fios da vida, um vai-e-vem que une diferentes épocas, lugares e pessoas. E como falar dos esquecimentos dentro deste elo sem fim que valoriza a lembrança? Nancy Huston nos propõe uma história surpreendente que aponta para a fabulação humana. Em seu livro L'espèce fabulatrice ela conta a história da convivência entre seu pai e uma inesperada sequela após uma cirurgia de cérebro. Ao invés de perder suas lembranças como a maioria dos recém-operados, seu pai começou a inventá-las. Tudo acontecia como aqueles momentos vivenciados como "déjà-vus": o pai se lembrava de modo coerente e convincente de momentos que jamais existiram. "Estas falsas lembranças, precisas e detalhadas, conseguiam se misturar às verdadeiras. Elas perturbavam gravemente sua existência. Tudo o que dizíamos, ele tinha a certeza de já ter ouvido. Tudo o que sugeríamos que ele fizesse, ele tinha certeza de que já tinha feito" (HUSTON, 2008, p. 68). Se para os filhos as "falsas lembranças" conseguiam propiciar alguns momentos cômicos, para o pai era profundamente desagradável ser contestado reiteradas vezes quando pensava estar certo do que dizia. Enfim, Nancy pretende nos mostrar através da história de seu pai, a quem dedica este livro, a profunda tendência humana a criar fabulações. Para ela o "cérebro lesionado" do pai nada mais era do que um "cérebro contador de histórias", um cérebro fiel à ideia de que "nossa condição é a ficção [...] Cabe a nós torná-la interessante" (HUSTON, 2008, p. 192).

Com esta história, Nancy pretende mostrar que tanto o esquecimento quanto as lembranças são construções fabulativas que moldam nossas práticas quotidianas. Assim, o que Cony chama de quase memória é nada mais do que entendemos por memória, um jogo de fazer e refazer no qual inexiste a totalidade. Toda memória é quase verdade e quase ficção, um quase de via dupla que pode não ser percebido, como na história do pai da escritora. 
Ou que, por outro lado, pode ser buscado e efetivado nas escritas nas quais as associações avançam livremente tornando-nos "cúmplices da memória". Como afirma Cony, "prefiro mergulhar na lembrança dele, em tudo o que foi e quis ser. É fórmula covarde para fugir. Diante da memória, sou mais cúmplice do que testemunha" (CONY, 1995, p. 156). Cúmplice, pois permite agir sem muito questionar, cúmplice, pois acompanha, coopera e entende suas nem sempre claras razões.

Paula se mostrou, caprichosamente, uma escritora de reconhecida aptidão fabulatória e confessou estar preenchendo os vazios da memória com imaginação. Acreditamos que tinha dentro de si a "secreta esperança de estar inventando certo" (TELLES, 2009, p. 5), o desejo de se utilizar da escrita no presente para recriar o passado e modificar a seu gosto a vida do avô - e, consequentemente, a de toda a sua família e de si mesma.

A personagem Véra, aos sete anos, afirma depois da morte do avô que "eu quase podia escutar sua voz grave me dizendo estas palavras, e ao mesmo tempo tudo isto me parecia um jogo" (HUSTON, 1992, p. 58), um jogo no qual Paula e Cony "não desgrudara[m] o olhar e a memória daquele pacote" (CONY, 1995, p. 79), um jogo de escrita, de verdade e de ficção.

O fato é que o pacote remetia o filho a uma pasta onde ele guardava tudo o que lembrava o pai, uma pasta herança com postais e cartas. Uma pasta que tinha pertencido ao pai e que agora servia para uni-los ainda mais. Diante do embrulho misterioso, Cony decide: "quando voltar para casa, a primeira coisa que farei será procurar a pasta. É nela também que deverei guardar esse embrulho que está na minha frente" (CONY, 1995, p. 171). Assim, o embrulho convida o filho a se debruçar na herança do pai e procurar a já encardida pasta para abri-la, relê-la e revivê-la. Um retorno pelos caminhos da memória e pela redescoberta de uma documentação - farta ou não - que se torna inventário da vida do pai. Para Paula, o magro e confuso inventário demonstra as dificuldades e as limitações de Paddon, um percurso pela escrita, pela memória e pela fabulação.

Se Paula escreve movida por uma promessa - embora escrevesse mesmo sem ela - Cony nos dá pistas de um projeto especial que deveria se realizar pelo viés narrativo. Por mais de uma vez, fala que seu pai pedira sua ajuda para realizar um projeto, projeto sempre adiado e nunca revelado aos leitores. Depois, confessa que dentro do embrulho tem uma história a ser publicada. Ele se lembra que o pai não apreciava a ficção escrita, mas que poderia "fazer chegar este texto a alguém que pudesse dele tomar conhecimento, e quem sabe, publicá-lo" (CONY, 1995, p. 136). Desta maneira, ao fazer associações não muito claras, Cony parece dizer aos leitores que o embrulho era o pedido do pai para a retomada do projeto especial.
O embrulho era um código, um contato do pai que lhe dizia que já era chegada a hora e que suas histórias deveriam ser escritas e publicadas. Se por um lado esta missão acalmaria as angústias e incertezas do filho ao escrever sobre o pai, ela o impele a um projeto que não é somente seu, um projeto, assim como o de Paula, a quatro mãos. Mais uma vez, diante de uma impossibilidade, os pais deixam uma herança a ser apreciada e redigida formalmente pelos filhos. Um emaranhado confuso, vivo e descontínuo de lembranças e histórias que se realizam pela seleção e pelo trabalho da escrita.

Paula consegue suportar o peso de sua herança graças à capacidade criativa de transformar os magros manuscritos que recebe em uma narrativa redentora. Diante da possibilidade de copiar o que foi deixado por Paddon, ela se serve timidamente do que ele lhe legou para seguir seus próprios passos em direção à construção ficcional de seu avô. Diante da folha em branco, não aceita escrever o que ela e ele viveram. Não o faz porque qualquer reprodução é subjetiva e nega veementemente a ideia da exatidão do "tal qual". Paula tem consciência desta liberdade na escrita e brinca com suas adivinhações, admitindo jogar com sua memória.

Um embrulho que não precisou ser aberto, que por si só permitiu ao filho escrever. Como ele mesmo define: "Eu passara as últimas horas numa viagem pela memória e tudo aqui o fora ficou absurdo, irreal. Ou real demais. [...] Não gostaria de encerrar esse dia, pudesse, eu o prolongaria, até o infinito da memória" (CONY, 1995, p. 219). Para Cony, o pai "mandou-me uma mensagem que eu não preciso abrir nem ler" (CONY, 1995, p. 221), uma mensagem esperada pelo filho, uma mensagem mote que o certificou da necessidade de se registrar as histórias e a vida do pai. Uma mensagem que foi, no limite, inventada e fabricada pelo próprio filho, pelo desejo incondicional de romper sua solidão. $\mathrm{O}$ desejo de dedicar nem que fosse um dia para degustar lembranças que saltaram aos montes de uma caixa que nem precisou ser aberta. Lembranças latentes que encontraram um motivo ou um quase motivo para ganharem todos os espaços da rotina atribulada do filho. Um dia em que, seguindo o lema de seu pai, Cony realizou uma grande coisa: uma quase memória, um quase romance. $\mathrm{Ou}$, um romance "mais que memória", como defende Marcelo Backes em um livro homônimo (2007). Reitera-se a ideia de que ao serem escritas, as lembranças são reconhecidamente transformadas pela ficção, assumindo o lugar do quase ou um lugar para além da memória.

\section{Referências}

ANDRADE, Carlos Drummond de. "Resíduo". A rosa do povo. Rio de Janeiro: Record, 1984. 
BACKES, Marcelo. Maisquememória: caderno europeu de viagens. Rio de Janeiro: Record, 2007.

BOSI, Ecléa. O tempo vivo da memória - ensaios de Psicologia Social. São Paulo: Ateliê Editorial, 2003.

CAMUS, Albert. L'étranger. Paris: Folio, 1990.

CONY, Carlos Heitor. Quase memória. Rio de Janeiro: O GLOBO, 2003.

HUSTON, Nancy. Trois fois septembre. Paris : Seuil, 1989.

HUSTON, Nancy; HUSTON, Léa. Véra veut la vérité. Paris: Mouche de poche, École des loisirs, 1992.

HUSTON, Nancy. Cantique des plaines. Paris: Actes Sud/ Montréal: Lémeac, 1993.

HUSTON, Nancy. Nord perdu, suivi de Douze France. Montréal: Lémeac, 1999.

HUSTON, Nancy. Une adoration. Montréal: Lémeac, 2003.

HUSTON, Nancy. Âmes et corps. Montréal: Leméac, 2004.
HUSTON, Nancy. L'espèce fabulatrice. Montréal: Lémeac, 2008.

LANDOWISKI, Eric. Presenças do outro. São Paulo: Perspectiva, 2002.

LE GOFF, Jacques. História e memória. São Paulo: UNICAMP, 2003.

PESSOA, Fernando. Poemas escolhidos. São Paulo: KLICK, 1997.

PROUST, Marcel. Du côté de chez Swann. Paris: Folio classique, 2004.

TELLES, Lygia Fagundes. Invenção e memória. São Paulo: Companhia das Letras, 2009.

Recebido: 16 de outubro de 2014

Aprovado: 26 de dezembro de 2014

Contato: vanessamassonirocha@gmail.com 